\title{
An ecosystem approach to malaria control in an urban setting
}

\author{
Uma abordagem ecossistêmica ao controle \\ da malária em contexto urbano
}

\footnotetext{
${ }^{1}$ Health Division - FES Foundation. Calle 23 Norte \#5-AN-47, Cali, Colombia. 2 Departamento de Microbiología, Facultad de Salud, Universidad del Valle. Apartado Aereo 2188, Cali, Colombia.
}

\begin{abstract}
We conducted a research project aimed at strengthening local government and the community for a sustainable malaria control strategy. The project began with a baseline diagnosis of malaria prevalence, a KAP survey, entomology, and health services delivery, after which an epidemiological study was performed to identify risk factors associated with malaria, thereafter used to plan intervention measures. A program evaluation was conducted five years later. By using an ecosystem approach to reanalyze data, this paper discusses how malaria arises from a complex interaction of cultural, economic, ecological, social, and individual factors. Intervention measures require an intersectorial and transdisciplinary approach that does not exist at the moment. Health sector leadership is limited, and there is no true community participation. Implications for research, including the use of qualitative and quantitative methods, study design, and complexity of data analysis are discussed. Finally, implications for malaria control are discussed, stressing the differences between the ecosystem and integrated disease control approaches.
\end{abstract}

Key words Malaria; Ecosystem; Prevention and Control; Public Health; Health

Resumo Os autores implementaram um projeto de pesquisa voltado ao fortalecimento do governo local e da comunidade com vistas à estratégia sustentável de controle da malária. O projeto iniciou com diagnóstico prévio, incluindo prevalência da malária, entomologia, KAP (conhecimentos, atitudes e práticas) e oferta de serviços de saúde; a seguir, realizou-se inquérito epidemiológico para identificar fatores de risco associados à malária e a escolha de medidas de intervenção adequadas. O programa foi avaliado após cinco anos. Ao adotar a abordagem ecossistêmica para re-analisar os dados, o artigo discute como a malária surge a partir da interação complexa entre fatores culturais, econômicos, ecológicos, sociais e individuais. Medidas de intervenção exigem abordagem intersetorial e transdisciplinar ainda não existente. A liderança do setor de saúde é limitada e não há participação comunitária de fato. Os autores examinam os envolvimentos para a pesquisa, incluindo o uso de métodos qualitativos e quantitativos, o desenho metodológico e a complexidade da análise dos dados. Por fim, discutem as implicações para o controle da malária, enfatizando diferenças entre abordagens ecossistêmicas e de controle integrado da doença.

Palavras-chave Malária; Ecossistema; Prevenção e Controle; Saúde Pública; Saúde 


\section{Introduction}

Despite technological advances in research, diagnosis, prevention, and treatment, malaria is still one of the world's most serious health problems. The World Health Organization (WHO) has recognized that eradication is not feasible, and various control strategies have been proposed.

The Integrated Approach to Malaria Control on the Pacific Coast of Colombia was a research project conducted from 1993 to 1997 in Buenaventura, Colombia's main Pacific port. The program involved three basic strategic concepts: epidemiological methodology, primary health care (PHC), and essential health research (EHR).

According to EHR premises, the scientific method should be applied to the search for answers to the main health problems in a given country. However, health research should involve not only scientists and universities, but also communities and health officials, to produce results that can be used for decision-making processes and policy development (Evans, 1990).

Epidemiology's general aims are to describe the health status of populations, explain etiology, predict occurrence, and control disease (Kleinbaum et al., 1982). We performed an initial diagnosis of the study area regarding the occurrence of malaria by time, person, and place in the previous five years; a study of the population's knowledge, beliefs, and practices towards malaria; a diagnosis of the degree of development of the primary health care (PHC) strategy in the area; and an entomological survey including vector bionomics and habits, breeding places, and anopheline species. After completing the description of the area, a crosssectional epidemiological survey was conducted to assess risk factors associated with malaria. Identification of risk factors was used to plan malaria control interventions, and an evaluation of the program was performed five years later.

The primary health care strategy defined by the World Health Assembly in 1977 was the basis for designing the intervention, because it is a comprehensive approach involving community participation, an intersectorial approach, use of appropriate technology for the level of complexity of the respective problem, and strengthening health services' management and capability for the public health response (WHO/UNICEF, 1978).

One of the main goals was to strengthen and encourage local government and the com- munity, since sustainability of a health intervention is achieved insofar as local authorities and communities themselves adopt the strategy. An external research agency may develop control measures, improve health delivery systems, or train health and community personnel. However, a research team cannot sustain a public health program for a long period of time.

\section{Socioeconomic and ecological history of malaria in Buenaventura}

Buenaventura, the main port on the Pacific coast of Colombia, has 260,000 inhabitants, $80 \%$ of whom live in the urban area, with approximately 60,000 inhabitants in the countryside in various dispersed villages. Mean annual temperature is $26{ }^{\circ} \mathrm{C}$, rainfall from 6000 to 8000 $\mathrm{mm} /$ year, and mean relative humidity $90 \%$, conditions that render the area highly vulnerable to malaria transmission.

Previous studies in rural areas have shown that risk is related to the specific village, but individual risk factors (age, number of persons in the household, education)(Carrasquilla, 1993) and occupational exposure (Balderrama \& Santander, 1985) have also been associated with malaria. The number of malaria cases in Buenaventura had been increasing before the project began. A trend towards a peak every four years was identified; meanwhile the proportion of urban cases had increased from 17\% in 1987 to $40 \%$ in 1991 (Mendez \& Carrasquilla, 1995).

\section{1) Factors associated with the occurrence} of malaria in the study area

The project was conducted in the poorest area of the city, with $45-55 \%$ of the population presenting unmet basic needs, an index used in Colombia for demarcating poverty. The unmet basic needs index for urban Buenaventura was $33.5 \%$.

a) Migration: Most of the migration (91.7\%) is internal from both urban and rural areas of Buenaventura (Sanchez, 1997). The study showed an association between migration and malaria. Among the families not subject to the intervention, those who had lived less than six months in the study area had a malaria incidence of 5.0 per 1000 , compared to $2.6 / 1000$ for those who had lived there for more than six months (Alvarado \& Alzate, 1998).

b) Location: The study area is the closest part of urban Buenaventura to the forest. In addition, there were numerous areas with tropical plants and bushes and many creeks form- 
ing pools along their beds. Most of the streets were unpaved, and puddles formed by vehicle tires were commonplace. Other investigators in Buenaventura (Carrasquilla, 1993; Alvarado, 1997) as well as in Sri Lanka (Gunawardena et al., 1998; Hoek et al., 1998) agree that proximity to wooded areas or water sources can be risk factors for malaria.

c) Economic activities: The main economic activities for the inhabitants of the study area were mining, lumbering, and fish-farming. Occupations involving exposure to the forest had the highest risk of malaria (Balderrama \& Santander, 1985; Mendez et al., 2000). Mining and fish-farming were risk factors, because out of the 26 breeding sites positive for Anopheles larvae, $16(61.5 \%)$ were mine pits and 3 (11.5\%) were fish ponds (Olano et al., 1997).

d) Climate: The Colombian Pacific coast is characterized by heavy rainfall $(6,000-8,000 \mathrm{~mm}$ per year). Malaria was inversely correlated with rainfall two months previously $(\mathrm{r}=-0.63,95 \% \mathrm{CI}$ : -0.88-0.09) and directly correlated with temperature highs one month previously $(r=0.69$, 95\% CI: 0.19-0.90) in 1991 (Mendez \& Carrasquilla, 1995). In Rwanda (Loevinsohn, 1994) and Pakistan (Bouma et al., 1996), temperature and rainfall have also been associated with malaria.

The post-ENSO (El Niño Southern Oscillation) year witnessed an increase of $35.2 \%$ in malaria cases in Colombia (Bouma et al., 1997) and $36.5 \%$ in Venezuela (Bouma \& Dye, 1997). Recent ENSO years 1987, 1991-1994, and 1997 have coincided with malaria peaks in Buenaventura.

e) Entomological factors: 28 (6\%) of 469 potential breeding sites in the urban area were positive for Anopheles larvae. 26 of these (93\%) were located in the study area (Olano et al., 1997). In a two-year follow-up, intradomiciliary and extradomiciliary bite rates were 0.95 and $3.79 \mathrm{bites/person/hour} \mathrm{for} \mathrm{Anopheles} \mathrm{albima-}$ nus and 1.06 and 2.84 for Anopheles nuñeztovari, respectively. Both of these vectors bite in the early evening, between 6:00 and 10:00 PM, with almost no activity after midnight. We found Plasmodium vivax sporozoites in two $(0.080 \%)$ out of 2499 A. albimanus females (Carrasquilla et al., s.d.).

f) Health services: The study area had a 24hour health center and two health posts. None of the three provided malaria diagnosis or treatment. Patients had to go to either the hospital or the former Malaria Eradication Service (SEM) clinic.

g) Community participation: The four elements of the PHC strategy were evaluated based on a score established by a group of experts. Community participation was rated at
$53 \%$, the intersectorial approach $0 \%$, management of health institutions $22.6 \%$, and health services organization $21 \%$ (Grigoriu \& Claros, 1992). Participation in health activities was limited to promotion and prevention as designated by health officials, but community leaders occasionally participated in problem identification, definition of priorities, and resource allocation.

h) Knowledge and practices: In four out of five neighborhoods where focus groups were conducted, malaria was identified as the most serious health problem (Nieto et al., 1999). Knowledge of preventive measures, age under 9 years, and use of antimalarials during the previous year were the factors associated with malaria in the study population (Mendez et al., 2000). Comparison of knowledge and practices between 1993 and 1997 showed that knowledge of the mosquito had increased by $17 \%$, elimination of breeding sites by $50 \%$, use of bednets by $187 \%$, and spraying by $189 \%$, all statistically significant. Use of bednets and spraying increased by $22 \%$ and $19.8 \%$, respectively (also significant). Self-medication for malaria in 1997 was half that of 1993. The malaria standardized morbidity ratio for the Buenaventura metropolitan area in 1997 was $20 \%$ of baseline in the areas where the intervention was implemented and $32 \%$ where the program was not, indicating a greater decrease in the program intervention areas (Alvarado \& Alzate, 1998).

i) Resistance: $71 \%$ of those who had taken chloroquine reported self-medication and at insufficient doses (Nieto et al., 1999). It should be stressed that $52 \%$ of patients with Plasmodium falciparum malaria were resistant to chloroquine (Barrera \& Carrasquilla, s.d.).

j) Individual risk factors: For the 20-39 year age group, those having rural occupations had a relative risk of 4.44 (95\% CI: $1.33-14.81)$ and those with urban occupations 0.49 (95\% CI: 0.25-0.98) as compared to the 0-9 year age group (Mendez et al., 2000). It has been reported consistently in the literature that malaria risk decreases with age (Carrasquilla, 1993; Alvarado, 1997; Mendez et al., 2000).

\section{2) Socioeconomic and ecological variables}

The factors described above were associated with malaria. However, they may include associations that confound or modify their relationship to malaria. In particular, income, cultural factors, and access to health services were associated with numerous other variables in different ways. 
Income was associated with use of both bednets and health services (Sanchez, 1997), (Mendez, 1994). Meanwhile, families contacted by the malaria education program decreased their malaria-related expenses by $55 \%$ because of improved access to diagnosis and treatment (Alvarado \& Alzate, 1998).

Cultural factors also play a role. Use of bednets (Nieto et al., 1999) and exposure to mosquito bites (Olano et al., 1997) are determined by the population's practices and beliefs. The $52 \%$ prevalence of chloroquine resistance in patients with $P$. falciparum may be related to over-the-counter medication, because there was no regulation of drug distribution. Knowledge of malaria symptoms and preventive measures by traditional healers were related to level of schooling (Wiest, 1995).

The factors statistically associated with access to health services in the case of malaria were age under 15 years, one or more years of schooling, lower index of economic dependence, and presence of antimalarials at home (Sanchez, 1997).

\section{3) Other characteristics}

Peak incidence of malaria cases in 1991 and 1992 coincided with the cholera epidemics, which had an important economic effect. Small-scale fishermen decreased their yields by $11.7 \%$ as compared to 1990 , and unemployment ranged from 19 to 53\% (Bonilla et al., 1994). We did not observe any effect on either hospitalization or in mortality due to malaria, tuberculosis, or perinatal problems during the epidemic (Carrasquilla et al., 1994).

Migration and circulating patterns within the ecosystem can change malaria exposure. Risk was different for those who entered the forest daily as compared to those who remained there for two weeks without returning to the village in the evenings. Washing clothes on the riverbanks may be also a risk factor, but not all women had the same level of exposure. Some only did laundry for their own families, but for others it was their means of living.

Future evaluation should consider the building of social capital (Coleman, 1993). Groups organized for the elimination of breeding sites, as well as those making and selling bednets, may have lasted and developed new activities not necessarily related to malaria control. Group members may have strengthened their leadership status and their ability to negotiate with community and government organizations. There was a decrease in the number of breeding sites in construction projects, proba- bly due to the stabilization of migration (Olano, 1998; Olano et al., 1997). In addition, the impact of health sector reform on the malaria control program merits further evaluation.

\section{4) Spatial and temporal scales}

Table 1 shows the spatial scales at which variables interacted in relation to malaria in the urban area of Buenaventura.

The project was intended to have an effect at the family and community level. Educational intervention to improve malaria-related knowledge acts at both the individual and family levels, as was shown in the households with a lower risk of malaria. However, interventions also act at other levels. Community participation functions at the neighborhood level, but organization of health services depends on the local government, as does the multisectorial approach to social development. Periurban characteristics (proximity to wooded areas and tropical vegetation) also operate at the community level.

Temporal scales also act during different periods. Two years after implementation of the program, self-medication had decreased significantly, and after four years of the program, knowledge and practices had changed in participating families. By 1995 we no longer observed the trend of a peak malaria incidence every four years. This was probably due to a combination of factors, including the program intervention, ENSO, stabilization of the population in District 12, and other unidentified factors. Rainfall and temperature bore a shortterm (one- to two-month) relationship with malaria.

Health sector reform, including decentralization and financing, require long periods of time for implementation at the State and municipal levels. Colombia holds municipal elections every three years, involving changes in the direction and priorities of health issues.

\section{Reinterpretation of findings}

There was a spatial aggregation of malaria cases. In urban Buenaventura, the downtown area, with $30 \%$ of the population, accounted for only $4 \%$ of all malaria cases, whereas District 12 , with $8 \%$ of the city's inhabitants, accounted for $41 \%$ of cases (Mendez \& Carrasquilla, 1995). The research project thus focused on areas where malaria was more frequent in order to describe its characteristics, determine risk factors, design and implement a control pro- 
Spatial scales at which variables interact for malaria in the urban area of Buenaventura, Colombia.

\begin{tabular}{|c|c|c|c|c|}
\hline Spatial scale & Cultural & Social & Economic & Ecological \\
\hline \multirow[t]{3}{*}{ Household } & $\begin{array}{l}\text { Knowledge, beliefs, and } \\
\text { practices determine use } \\
\text { of bednets, spraying, and } \\
\text { self-medication. }\end{array}$ & $\begin{array}{l}\text { Mother makes decisions } \\
\text { concerning use of } \\
\text { preventive measures } \\
\text { or health services. }\end{array}$ & $\begin{array}{l}\text { Health education } \\
\text { decreases expenses } \\
\text { for care of malaria cases. }\end{array}$ & $\begin{array}{l}\text { Rural occupation increases } \\
\text { risk of malaria after } \\
\text { controlling for other risk } \\
\text { factors. }\end{array}$ \\
\hline & $\begin{array}{l}\text { Exposure to vectors at the } \\
\text { highest biting rate occurs } \\
\text { at household level, but also } \\
\text { at the neighborhood or } \\
\text { barrio level. }\end{array}$ & & $\begin{array}{l}\text { Affordability is the main } \\
\text { constraint for use of health } \\
\text { services and preventive } \\
\text { measures. }\end{array}$ & $\begin{array}{l}\text { Mine pits become } \\
\text { breeding sites for } \\
\text { mosquitoes. }\end{array}$ \\
\hline & $\begin{array}{l}\text { A relative stops working to } \\
\text { take care of the sick person. }\end{array}$ & & $\begin{array}{l}\text { Fish ponds as source of } \\
\text { family income, but also a } \\
\text { potential breeding site } \\
\text { for mosquitoes. }\end{array}$ & \\
\hline \multirow[t]{3}{*}{$\begin{array}{l}\text { Neighborhood ("barrio"), } \\
\text { and district. }\end{array}$} & $\begin{array}{l}\text { Community participation: } \\
\text { groups for elimination } \\
\text { of breeding sites. }\end{array}$ & $\begin{array}{l}\text { People converse or play } \\
\text { dominos on the porches } \\
\text { of the homes at the time } \\
\text { of highest bite rates. }\end{array}$ & $\begin{array}{l}\text { Increasing number } \\
\text { of fish ponds. }\end{array}$ & $\begin{array}{l}\text { High proportion of } \\
\text { households with NBI. }\end{array}$ \\
\hline & & $\begin{array}{l}\text { We did not find that } \\
\text { bednets actually protected } \\
\text { against malaria. }\end{array}$ & $\begin{array}{l}\text { Groups for production and } \\
\text { distribution of bednets, } \\
\text { which improved family } \\
\text { income of participants. }\end{array}$ & $\begin{array}{l}\text { Location close to forest } \\
\text { and tropical vegetation. }\end{array}$ \\
\hline & & & & $\begin{array}{l}\text { Recently occupied area, } \\
\text { thus with much construction. } \\
\text { Digging for constructio } \\
\text { creates breeding sites. }\end{array}$ \\
\hline \multirow[t]{5}{*}{ Municipal government } & $\begin{array}{l}\text { Community organization } \\
\text { often depends on external } \\
\text { agents. }\end{array}$ & $\begin{array}{l}\text { Local authorities have not } \\
\text { committed themselves } \\
\text { to malaria control activities. }\end{array}$ & $\begin{array}{l}\text { Municipal government } \\
\text { did absorb the cost of } \\
\text { continuing the program. }\end{array}$ & \\
\hline & $\begin{array}{l}\text { Community participation } \\
\text { limited to participation } \\
\text { in health promotion and } \\
\text { prevention, activities } \\
\text { programmed by the health } \\
\text { authorities, without taking } \\
\text { community preferences, } \\
\text { priorities, etc. into account. }\end{array}$ & $\begin{array}{l}\text { Organization of health } \\
\text { services with new } \\
\text { responsibilities for the } \\
\text { municipal government. }\end{array}$ & $\begin{array}{l}\text { Increased unemployment } \\
\text { rate. }\end{array}$ & \\
\hline & $\begin{array}{l}\text { Large number of traditional } \\
\text { healers. First choice for care, } \\
\text { prior to hospital and } \\
\text { health post. }\end{array}$ & $\begin{array}{l}\text { Politics plays a central role } \\
\text { in the health sector. }\end{array}$ & $\begin{array}{l}\text { The city has significantly } \\
\text { decreased economic } \\
\text { capability due to debt, } \\
\text { corruption, and lower tax } \\
\text { revenues. }\end{array}$ & $\begin{array}{l}\text { Lumbering is an important } \\
\text { economic activity. } \\
\text { Inhabitants of District } 12 \\
\text { work in the forest in } \\
\text { wood-cutting. Wood is } \\
\text { exported to Cali and } \\
\text { other cities of Colombia. }\end{array}$ \\
\hline & & $\begin{array}{l}\text { People no longer trust } \\
\text { politicians. Nor do they } \\
\text { believe in social or economic } \\
\text { leaders. }\end{array}$ & & \\
\hline & & $\begin{array}{l}\text { No intersectorial approach } \\
\text { for social development and } \\
\text { problem-solving activities. }\end{array}$ & & \\
\hline Region & $\begin{array}{l}80 \% \text { of the population } \\
\text { of African origin. }\end{array}$ & $\begin{array}{l}\text { Migration from rural areas } \\
\text { of the Pacific to } \\
\text { Buenaventura, usually as } \\
\text { a step prior to later } \\
\text { migration to Cali. }\end{array}$ & $\begin{array}{l}\text { Exploitation of timber } \\
\text { by multinational } \\
\text { companies. }\end{array}$ & $\begin{array}{l}\text { Rainfall, humidity, and } \\
\text { temperature foster high } \\
\text { malaria transmission rates. }\end{array}$ \\
\hline \multirow[t]{2}{*}{ Country/World } & $\begin{array}{l}\text { Decentralization of vertical } \\
\text { programs }\end{array}$ & $\begin{array}{l}\text { Changes in financing } \\
\text { of health services. }\end{array}$ & ENSO & \\
\hline & Health systems reform. & & & \\
\hline
\end{tabular}


gram, and evaluate results. However, individual, household, and citywide factors also had to be addressed.

In Buenaventura, and particularly in District 12, malaria hinges on a complex interaction of cultural, economic, ecological, social, and individual factors. Low income, low level of schooling, migration, cultural beliefs, low coverage of health services, employment patterns, forest management, and the environment are some of the determinants of malaria in the ecosystem described above. Solving such a complex problem requires an intersectorial and transdisciplinary approach that does not exist at the moment. Leadership in the health sector is limited, and there is no true community participation.

At the local level, politicians and the upper socioeconomic strata enjoy all the privileges. Owners and executives of the industrial fishing, lumbering, and international trade and port sectors do not live in Buenaventura themselves and consequently do not invest in the city. At the neighborhood level, there is little turnover among community leaders, who are always the same in such organizations as community boards, health committees, and political parties, thus enjoying little credibility in the community and failing to strive for community goals.

The local health authority is the Secretary of Health, who failed to make the decision to use the educational materials or to strengthen malaria diagnosis by community microscopists, because there was no political profit involved. He saw our research group as competition for him rather than a source of support for his activities.

With regard to the malaria control program itself, there has been a major struggle in recent years with the union of the former workers from the Malaria Eradication Service. Due to the decentralization process in vertical programs, MES workers were allocated to the State level but with no resources. They stopped performing malaria control activities (diagnosis, treatment, and spraying) in both urban and rural areas. They have continued to receive their wages and work benefits, but malaria control activities have suffered, affecting the poorest communities.

Women are the main actors in the system. The proportion of households whose main source of income is women is higher than for the country as a whole (28\%). Women make the decisions in the use of preventive measures and health care services. In addition, community health groups, primary school teachers, primary health care providers, and traditional healers are mostly women. This was why the educational materials were mainly prepared by and for women.

\section{Implications for ecosystem management}

To solve problems in malaria control, new forms of organization must be defined and negotiated (Waltner-Toews \& Wall, 1997). Malaria control activities require coordination among government agencies (at the national, State, and municipal levels), nongovernmental organizations (including research groups), and communities. In particular, coordination among research groups, decision-makers, and the community should be emphasized.

Target communities and primary health care should be coordinated for continuous education, improved access to health services, and vector control. In our case, community involvement was extensive in the design of educational materials and production and distribution of bednets.

An ecosystem approach with a post-normal perspective on health problems requires different indicators according to the decision-making level, knowledge of the problem, and interventions required.

Basic indicators such as number of cases, treatment provided, and risk factors should be determined at the community and local health post levels. Identification and enumeration of potential breeding sites should also be performed at this level. Community leaders, health promoters, and health volunteers should have information on the use of bednets, malaria cases, malaria-like symptoms, and individuals with positive thick smears, because they are able to implement specific interventions. Indicators for local level authorities, research groups, and decision-makers should also be defined.

\section{Implications for research}

An ecosystem approach requires both quantitative and qualitative methods. The first is needed to describe individual variables, household characteristics, ecological and climatic variables, and use of health services. The latter is necessary to analyze relations between different variables on different scales. Focus groups, participatory observation, and in-depth interviews should be utilized. 
An ecological design should be used, because it takes into account different levels of aggregation, inference, and analysis according to individual, ecological, and global variables (Morgenstern, 1998). The epidemiological method can be complemented with methods from the social sciences, economics, GIS (Geographic Information Systems), and the environmental and climatic sciences, requiring a transdisciplinary research team with expertise in the above areas. An experienced biostatistician is mandatory. Such a group requires researchers with strong leadership skills, teamwork, and openness to different opinions, work methods, and conceptual frameworks. Such a group must learn how to deal with uncertainty and complexity in order to avoid being overly deterministic, in particular when dealing with health issues at the population level. The research team should include a social communicator to present results to the community, health authorities, politicians, and the media. A communications strategy for the project should be defined at the very beginning of the program.

The community should be involved from the beginning, when the research questions are being developed by the researchers, and should continue during the field work, data collection and analysis, and discussion of results, reports, and Publications. In particular, women's participation is highly relevant given that they are the main actors in malaria control interventions under the ecosystem approach described above.

Data collection and recording require a major effort, because of the amount of information with a great variety of characteristics. For quantitative data, designing an adequate data base allows a program to deal with variables of different levels and scales. For qualitative information, categories should be defined for analysis with available software.

New indicators should emerge for monitoring the ecosystem's health. The set of indicators should be agreed upon by the different participating disciplines. Construction and validation of such indicators should be an emphasis of the project.

\section{Relationships between the ecosystem approach and integrated disease control}

According to the World Health Organization, “...the goal of malaria control depends on a change in emphasis from highly prescriptive, centralized control programs to flexible, cost-effective and sustainable programs adapted to local conditions and responding to local needs..." (WHO, 1992:58).

An ecosystem approach, on the other hand, must accommodate both basic scientific work and participatory activity, emphasizing sustainable health rather than disease control activities. According to this view, health promotion uses negotiation and conflict resolution in the context of holarchy. Information generated by research should empower the people who need it. Public health research should be embedded in the context of real human activities, where all the problems of uncertainty and complexity come into full play (Waltner-Toews, in this fascicle).

While integrated control rests in the leadership of the health system, the ecosystem approach requires broader participatory involvement by different driving forces and interests.

In our research, we acted under the framework of integrated control, but used some elements from the ecosystem approach. However, we did not succeed in involving other actors, especially politicians and local authorities, that could have contributed to the program's sustainability. We did not have in mind the two basic elements of the ecosystem approach, holarchy and feedback loops (Waltner-Toews, in this fascicle). 


\section{Acknowledgments}

This project was funded by the WHO/World Bank/ UNICEF Special Program for Training and Research in Tropical Diseases (TDR) and the FES Foundation. Additional funds were obtained from Foster Parents International, Manos Unidas, the Pan-American Health Organization, Universidad del Valle, Fundación Restrepo Barco, and Valle State Secretariat of Health. This document was funded by the International Development Research Center (IDRC) for the meeting "An Ecosystem Approach to Human Health and Communicable and Emerging Diseases", held at the Brazilian National School of Public Health, Oswaldo Cruz Foundation, Rio de Janeiro, November 8-12, 1999.

\section{References}

ALVARADO, B. \& ALZATE, A., 1998. Evaluación de una Estrategia de Fortalecimiento en Participación Comunitaria para el Control de la Malaria en Área Urbana de Buenaventura. Cali: Centro de Investigaciones en Epidemiología, Universidad del Valle.

ALVARADO, B., 1997. Relación entre los Conocimientos, Actitudes y Prácticas con la Prevalencia de Malaria en Localidades Rurales de los Municipios de Buenaventura y Litoral del San Juan. Tesis de Maestría, Cali: Universidad del Valle.

BALDERRAMA, F. \& SANTANDER, A. G., 1985. Riesgo de Infección Extradomiciliaria de la Malaria en Diferentes Ámbitos Ecológicos Ocupacionales en Bajo Calima, Buenaventura, Colombia. Tesis de Maestría, Cali: Universidad del Valle.

BARRERA, L. \& CARRASQUILLA, G., s.d. Chloroquine resistance in Buenaventura. (manuscript in preparation).

BONILLA, E.; RODRIGUEZ, P.; RAMIREZ, M.; DURANA, C. \& MONTENEGRO, A., 1994. Efectos Sociales y Económicos del Cólera en Colombia. Santafé de Bogotá: Universidad de los Andes.

BOUMA, M. J. \& DYE, C., 1997. Cycles of malaria associated with El Niño in Venezuela. JAMA, 278: 1772-1774.

BOUMA, M. J.; POVEDA, G.; ROJAS, W.; CHAVASSE, D.; QUIÑONEZ, M.; COX, J. \& PATZ, J., 1997. Predicting high-risk years for malaria in Colombia using parameter of El Niño Southern Oscillation. Tropical Medicine and International Health, 2:1122-1127.

BOUMA, M. J.; DYE, C. \& KAAY, H. J. V. D., 1996. Falciparum malaria and climate change in the Northwest frontier province of Pakistan. American Journal of Tropical Medicine and Hygiene, 55:131-137.

CARRASQUILLA, G., 1993. Epidemiology of Malaria in Low Endemic Areas. Ph.D. Thesis, Boston: Harvard University.
CARRASQUILLA, G.; DELGADO, F.; CORAL, O.; MAZUERA, N. \& CONCHA, A., 1994. Efectos de la Epidemia del Cólera en los Servicios de Salud de Buenaventura y Tumaco. Cali: Fundación FES.

CARRASQUILLA, G.; OLANO, V.; OSORIO, Y.; MENDEZ, F.; VALDERRAMA, L. \& BARRETO, M., s.d. Intensity of transmission in an urban area of the Colombian Pacific coast. (manuscript in preparation).

COLEMAN, J. S., 1993. Social capital in the creation of human capital. American Journal of Sociology, 94: 95-120.

EVANS, J. R., 1990. Essential National Health Research: A key to equity for development. New England Journal of Medicine, 323:913-915.

GRIGORIU, C. \& CLAROS, L. M., 1992. Tesis de Maestría, Cali: Universidad del Valle.

GUNAWARDENA, D. M.; WICKREMASINGHE, A. R.; MUTHUWATTA, L.; WEERASINGHA, S.; RAJAKARUNA, J.; SENANAYAKA, T.; KOTTA, P.; ATTANAYAKE, N.; CARTER, R. \& MENDIS, K. N., 1998. Malaria risk factors in an endemic region of Sri Lanka, and the impact and cost implications of risk factor-based interventions. American Journal of Tropical Medicine and Hygiene, 58:533-542.

HOEK, W. v.d.; KONRADSEN, F.; DIJKSTRA, D. D.; AMERASINGHE, P. H. \& AMERASINGHE, F. P., 1998. Risk factors for malaria: A microepidemiological study in a village in Sri Lanka. Transactions of the Royal Society of Tropical Medicine and Hygiene, 92:265-269.

KLEINBAUM, D.; KUPPER, L. \& MORGENSTERN, H., 1982. Epidemiologic Research: Principles and Quantitative Methods. Belmont: Lifetime Learning Publications.

LOEVINSOHN, M. E., 1994. Climatic warming and increased malaria incidence in Rwanda. Lancet, 343:714-718.

MENDEZ, F. \& CARRASQUILLA, G., 1995. Epidemiología de la malaria en el área urbana de Buena- 
ventura: Análisis de la ocurrencia en el período 1987-1993. Colombia Médica, 26:77-84.

MENDEZ, F., 1994. Epidemiología de la Malaria en el Área Urbana de Buenaventura: Análisis de la Ocurrencia en el Período 1987-1993 y Factores de Riesgo Asociados a la Prevalencia de Infección en la Comuna 12. Tesis de Maestría, Cali: Universidad del Valle.

MENDEZ, F.; CARRASQUILLA, G. \& MUÑOZ, A., 2000. Risk factors associated with malaria infection in an urban setting. Transactions of the Royal Society of Tropical Medicine and Hygiene, 94:367-371.

MORGENSTERN, H., 1998. Ecologic studies. In: Modern Epidemiology (K. J. Rothman \& S. Greenland, eds.), pp. 459-480, Philadelphia: Lippincott-Raven.

NIETO, T.; MENDEZ, F. \& CARRASQUILLA, G., 1999. Knowledge, beliefs and practices relevant for malaria control in an endemic urban area of the Colombian Pacific. Social Science and Medicine, 49:601-609.

OLANO, V., 1998. Evaluación Entomológica en Buenaventura, Valle - 1997. Bogotá: Fundación FES, Instituto Nacional de Salud.

OLANO, V.; CARRASQUILLA, G. \& MENDEZ, F., 1997. Urban malaria transmission in Buenaventura,
Colombia: Entomological aspects. Pan American Journal of Public Health, 2:378-385.

SANCHEZ, P., 1997. Uso de Servicios de Salud en la Comuna 12 de Buenaventura: Análisis de la Prevalencia en un Período de 1995 y sus Factores Determinantes. Tesis de Maestría, Cali: Universidad del Valle.

WALTNER-TOEWS, D. \& WALL, E., 1997. Emergent perplexity: In search of post-normal questions for community and agroecosystem health. Social Science and Medicine, 45:1741-1749.

WHO (World Health Organization), 1992. Implementation of the Global Malaria Control Strategy. Geneva: World Health Organization.

WHO/UNICEF (World Health Organization/United Nations International Children's Emergency Fund), 1978. Primary Health Care. Geneva: WHO.

WIEST, A., 1995. Estudio Descriptivo sobre los Proveedores no Estatales de Servicios de Salud de la Comuna 12 de Buenaventura. Buenaventura: Instituto de Salud del Pacífico. 